the friction of the mercury are avoided by connecting the vessels by wires with the earth.

If $\mathrm{H}$ and $\mathrm{I}$ form a mass of lead, I infer that three interchanges of $\mathrm{D}$ and $\mathrm{E}$ will be required, so that each weight shall be brought opposite the top and bottom of each mass to eliminate want of homogeneity in the lead. In the plan I propose only one interchange will be needed.

The effect, if any, of the vessels full of mercury being at
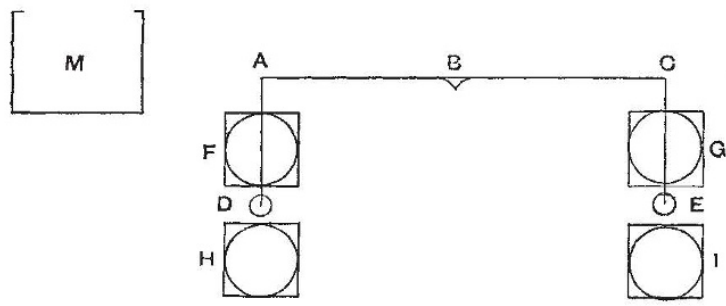

tunequal distances from the arms of the balance can be readily determined and allowed for.

The plan I suggest may have already presented itself to the eminent scientists who have originated their notable improvement on Von Jolly's plan. The pleasure I had in reading the account of their proposed research has prompted me to make these suggestions.

AlFRED M. MAYER

Stevens Institute of Technology, Hoboken, New Jersey, February 7

\section{Bees and Flowers}

As there is a prevailing idea that bees prefer red and blue to other colours, the following observations on their habits may be of interest:- The common hive bees were very busy among the flowers in the garden this morning. Those most frequented were yellow crocus, snowdrop, and Christmas rose. Next in order, winter aconite, yellow jessamire, and blue scilla. On sweet blue violets and on a dwarf erica, which is now flowering, I could see none. Hitherto my observations led me to suppose they never visited the blue scilla for honey, as I had never seen them settle down to it in a business-like manner, but simply flit over it and go to something else.

G. W. BULMAN

Corbridge-on-Lyne

\section{Free Lectures}

I OBSERVED in NATURE for February I9 (p. 367) a reference to the free lectures at Liverpool, and the inquiry, Why cannot the same thing be done in other large towns? It may interest your readers to learn that a series of free lectures has been given during the past two winters by the professors of this College. Tickets for these lectures are distributed through the agency of a committee composed partly of employers, and the attendance at each lecture numbers between 600 and 700 . The audience consists wholly of persons in receipt of weekly wages, the services of the lecturers are given gratuitously, and no charge whatever is made for admission. The small expenses of printing and issuing programmes and tickets are defrayed by the Committee. I inclose the syllabus of this, the second year's course, now drawing to a conclusion.

In addition to these lectures we have from time to time free lectures by gentlemen possessing special knowledge of the contents of the Free Libraries. These, too, are attended by a large number, chiefly of working people, and when the art gallcries are completed next year arrangements of a similar kind will doubtless be made in connection with them WILLIAM A. TILDEN

The Mason Science College, Birmingham, February 24

\section{A Tracing Paper Screen}

I CAN add to the testimony of Mr. Charles Taylor about the efficiency of a screen of tracing paper. I have used for several years a small screen of tracing cloth mounted on rollers like a map. It is very portable and soo. fixed. With a sciopticon lantern (oil lamp) I have shown transparencies in the winter months to an audience of seven hundred men in a. Mirland Railway mess-room during the breakfast hour-8.15 to 8.50 a.m.-thongh the windows are by no means in the best position, and the room is lighted hy skylights as well as by side windows. It is a pity this screen is not better known and more extensively used for scientific lectures.

Irongate, Derby, February 28

H. ARNold Bemrose

Febriary 28

\section{An Author's Gratitude}

I WISH to express my gratitude to NATURE and to the reviewer in NATURE of my little pamphlet on Electrical Units for exposing a compound error by which the farad came to be described as a fraction of the electrostatic C.G.S. unit of capacity instead of the electro-magnetic unit. Was there ever a greater-blunder? It was as if I had said the value of the tenth part of a farthing is sufficient to pay off a million times the National Debt of Great Britain. On recovering from the shock occasioned by the revelation, I hastened to the printer, and got him to correct the error " ere the sun went down," and now I overflow with gratitude to your reviewer, who has relieved me of the awful incubus of an error of the $10^{20}$ magnitude.

RICHARD WORMELI

\section{SCIENTIFIC LABORATORIES ${ }^{1}$}

I FEEL that the present occasion, upon which you have done me the honour to ask me to preside, is one of very great importance indeed, and I wish some person more competent to preside on such an occasion and give a suitable inaugural address were in my place. I am afraid I must confine myself to something not at all worthy of the greatness of an occasion which is almost the opening of a new university. Not quite so, because the real opening of this college took place several months ago; but still it is an occasion which I feel to be much more than merely the opening of a department-a working department-in the college; an occasion of so great moment that I regret that I shall not be able to give anything that could be properly considered a worthy inaugural acldress. I shall be obliged to ask your indulgence if I confine myself specially to departments with which I am personally familiar-scientific laboratories. The laboratory of a scientific man is his place of work. The laboratory of the geologist and of the naturalist is the face of this beautiful world. The geologist's laboratory is the mountain, the ravine, and the seashore. The naturalist and the botanist go to foreign lands, to study the wonders of nature, and describe and classify the results of their observations. But they must do more than merely describe, represent, and depict what they have seen. They must bring home the products of their expeditions to their studies, and have recourse to the appliances of the laboratory properly so-called for their thorough and detailed examination. The naturalist in his laboratory with his microscope and appliances for the keenest examination, learns to know more than can be learned by merely looking at external beauties. The geologist brings his specimens to the chemist-is himself a chemist perhaps-brings his crystals to the physical laboratory to be examined as to their physical properties, their hardness, the angles between their faces, their optical qualities. Some people might think this an ignoble way to deal with crystals. But it is not so to the trained cye and deeper thought of the scientific man. The scientific man sees and feels beauty as much as any mere observer-as much as any artist or painter. But he also sees something underlying that beauty; he wishes to learn somcthing of the actions and forces producing those beautiful results. The neccssity for study below the surface seems to have been earliest recognised in anatomy, and earliest carried out in human anatomy. I am not going to speak of the work of scientific research generally, but with reference to the special occasion which brings us here this day-the opening of the chemical and physical laboratories of the University College of North Wales. I am going to speak

r Address by Prof. Sir William Thomson, F.R.S., on the occasion of the opening of the Lahoratories of University College, Pangor. 